\title{
CCXXI. STUDIES IN GLYCOLYSIS
}

\section{APOMYOZYMASE AND THE COENZYMES OF GLYCOLYSIS IN MUSCLE EXTRACTS}

\author{
BY LAURENCE POLLARD KENDAL ${ }^{1}$ \\ AND LEONARD HUBERT STICKLAND \\ From the Department of Experimental Pathology and Cancer Research \\ in the University of Leeds
}

(Received 19 July 1937)

IN the course of some experiments involving the use of rabbit muscle extracts as glycolysing systems, it was found that adenylpyrophosphate and $\mathrm{Mg}$ ions could not effectively replace boiled muscle extract ${ }^{2}$ in restoring the activity of dialysed enzyme solutions. This observation was not in accord with the experience of Meyerhof \& Lohmann at that time (1935). Lohmann [1931, 1, 2] had found $\mathrm{Mg}^{++}+$adenylpyrophosphate equivalent to boiled muscle extract in coenzymic function. The solution of the apparent discrepancy was found to lie in the fact that Meyerhof \& Lohmann had diluted their muscle extracts only about twice during the estimation of glycolytic activity, whilst in the experiments referred to above the extracts had been diluted 5-10 times. It seemed possible therefore that muscle extract, even after dialysis, contained some essential coenzyme other than $\mathrm{Mg}$ ions and adenylpyrophosphate. The presence of this coenzyme appeared to be demonstrated by the reduction of its concentration much below an effective level when the extract was diluted, and the deficiency thus caused could be remedied by the addition of boiled extract.

During the period in which the nature and role of this new coenzymic factor have been under investigation, the participation of two more coenzymes in muscle glycolysis has been reported from other laboratories. Bauer [1936] found that in muscle extract diluted 2000 -fold the speed of the reversible conversion of hexosediphosphate into triosephosphate is very slow, but can be increased by addition of boiled extract. Meyerhof \& Ohlmeyer [1936], using very thoroughly dialysed extracts, demonstrated the need for cozymase to activate the oxidoreductive reaction between triosephosphate and pyruvic acid. All the types of muscle extracts used in the experiments described in this paper have been shown to suffer from no deficiency of the Bauer coenzyme. The effect of the addition of cozymase together with $\mathrm{Mg}^{++}$and adenosinetriphosphate was examined at an early stage in the investigation, but this combination of coenzymes was not able effectively to replace boiled extract. Whilst evidence has been obtained which confirms the view of Meyerhof \& Ohlmeyer that cozymase is probably a necessary component of the coenzyme system, the experiments to be reported here show that in addition to $\mathrm{Mg}^{++}$, adenosinetriphosphate and cozymase some other coenzyme plays an equally important part.

1 Bertram Parkinson Fellow.

2 "Boiled extract" is used throughout as the equivalent of the German "Kochsaft". 


\section{EXPERIMENTAL}

For the preparation of boiled extract, muscle was taken from a rabbit immediately after the animal was killed, and cooled in an ice-salt freezing mixture. It was minced in an ice-cold mincing machine and added to its own volume of boiling $N / 500 \mathrm{NaOH}$. The whole was boiled for 2-3 min. and filtered at the pump. After cooling, the $p \mathrm{H}$ was adjusted to $7 \cdot 4$ by the addition of $40 \%$ $\mathrm{NaOH}$. This preparation was found to be quite as active as those made by the usual method of boiling muscle with $1 \% \mathrm{Na}_{2} \mathrm{HPO}_{4}$, and had the advantage for many purposes of containing much less phosphate. $2 \mathrm{ml}$. of such a boiled extract were used in $5 \mathrm{ml}$. of reaction mixture in glycolysis tests; the use of larger amounts caused no further significant increase in the rate of lactic acid formation in dialysed muscle extracts. It was often desirable to add coenzyme in a less bulky form, and for this purpose the boiled extract was concentrated by distillation under reduced pressure at a temperature not higher than $40^{\circ}$. No loss in activity resulted from this treatment.

The silver salt of adenosinetriphosphate was prepared by the method of Barrenscheen \& Filz [1932]. Solutions were made up as required by decomposing this in $M / 25 \mathrm{MgCl}_{2}$ to give a solution $M / 200$ with respect to adenosinetriphosphate. $0.5 \mathrm{ml}$. of this solution was used per $5 \mathrm{ml}$. reaction mixture, giving final concentrations of $M / 2000$ adenosinetriphosphate and $M / 250 \mathrm{Mg}^{++}$. The use of higher concentrations of these substances gave no significantly greater degree of activation of glycolysis.

Solutions of $\mathrm{Na}$ hexosediphosphate were made from the commercial Ca salt by treatment with oxalic acid, removal of the $\mathrm{Ca}$ oxalate and neutralization with $\mathrm{NaOH}$.

Cozymase was obtained from D.C.L. yeast by the method of Ohlmeyer [1936]. After decomposition of the $\mathrm{Hg}$ salt and removal of $\mathrm{HgS}$ and residual $\mathrm{H}_{2} \mathrm{~S}$ the cozymase was precipitated with acetone, dried in vacuo and stored at room temperature in a desiccator over sulphuric acid. For activity tests apozymase prepared from yeast kindly supplied by the Red Tower Lager Brewery, Ltd., Manchester, was used. The conditions laid down by Myrbäck [1928] were observed, but unfortunately no standard cozymase or apozymase was available for comparison, so that the potency of the preparation cannot be stated in terms which would be really comparable with those used by other workers. $1 \mathrm{mg}$. of the product was found to be equivalent in cozymase activity to about $1.3 \mathrm{ml}$. of boiled yeast juice and to about $1.0 \mathrm{ml}$. of boiled muscle extract.

In each measurement of glycolysis described in this paper, the total volume of solution incubated was $5 \mathrm{ml}$. The solutions contained $0.5 \%$ starch, $0.25 \%$ $\mathrm{NaHCO}_{3}, 0 \cdot 6-0 \cdot 8 \mathrm{mg}$. $\mathrm{P} / \mathrm{ml}$. as inorganic phosphate at $p \mathrm{H} 7 \cdot 4$ and the necessary amount of enzyme solution. All other solutions added were adjusted to $p \mathbf{H ~} \mathbf{7 \cdot 4}$ before use. These reaction mixtures were placed in the vessels of Barcroft differential manometers and incubated, with shaking, in an atmosphere of $\mathrm{N}_{2}+5 \% \mathrm{CO}_{2}$ in the usual way. Manometric observations were sometimes taken as an indication of lactic acid production in preliminary experiments, and at the end of the experimental period the solutions were made up to $25 \mathrm{ml}$. with $5 \%$ trichloroacetic acid and filtered. The lactic acid in them was estimated by the method of Friedemann et al. [1927].

\section{Effect of dilution on the glycolytic activity of muscle extracts}

Extracts of rabbit muscle were prepared by the method of Meyerhof [1926]. The animal was killed by a blow on the neck. The muscle of the hind limbs and back was removed and cooled in ice as rapidly as possible. It was then minced 
in an ice-cold machine, pounded with $1 \frac{1}{2}$ vol. of distilled water and allowed to stand at $0^{\circ}$ for half an hour. The pulp was removed by centrifuging and the extract filtered. The $p H$ was adjusted to $\mathbf{7 \cdot 4}$, and after a preliminary dialysis in collodion sacs against running tap water the extract was dialysed against distilled water at $0^{\circ}$ for, usually, $24 \mathrm{hr}$. Such extracts will for convenience be referred to as $\mathrm{DM} x, x$ indicating the period of dialysis in hours.

The effect of dilution upon the glycolytic activity and coenzyme requirements of such extracts is shown in Table $I$.

Table I. The effect of dilution upon the glycolytic activity and coenzyme requirements of muscle extracts

\begin{tabular}{|c|c|c|c|}
\hline \multirow[b]{2}{*}{ Exp. } & \multirow[b]{2}{*}{$\begin{array}{l}\text { ml. of extract } \\
\text { (DM 24) in } 5 \mathrm{ml} . \\
\text { reaction } \\
\text { mixture }\end{array}$} & \multicolumn{2}{|c|}{ mg. lactic acid formed from starch in $1 \mathrm{hr}$. with } \\
\hline & & $\begin{array}{c}\text { Boiled extract } \\
\text { (concentrated } \times 4, \\
0.5 \mathrm{ml} .)\end{array}$ & $\begin{array}{c}\begin{array}{c}\text { Adenosinetri- } \\
\text { phosphate }\end{array} \\
(M / 2000)+M^{++}(M / 250)\end{array}$ \\
\hline 1 & $\begin{array}{l}4 \cdot 00 \\
1 \cdot 33 \\
0 \cdot 44 \\
0 \cdot 15 \\
0 \cdot 05\end{array}$ & $\begin{array}{l}9 \cdot 4(2 \cdot 3)^{*} \\
6 \cdot 5 \\
3 \cdot 9 \\
2 \cdot 8 \\
1 \cdot 3(26 \cdot 4)^{*}\end{array}$ & $\begin{array}{l}9 \cdot 5 \\
4 \cdot 4 \\
1 \cdot 8 \\
0 \cdot 6 \\
0 \cdot 1\end{array}$ \\
\hline $\begin{array}{l}2 \\
\mathbf{3} \\
\mathbf{4} \\
\mathbf{5} \\
\mathbf{6}\end{array}$ & $\begin{array}{l}0 \cdot 15 \\
0 \cdot 10 \\
0 \cdot 30 \\
0 \cdot 25 \\
4 \cdot 00\end{array}$ & \begin{tabular}{r|}
$2 \cdot 3$ \\
$3 \cdot 0$ \\
$3 \cdot 4$ \\
$3 \cdot 6$ \\
$11 \cdot 9$
\end{tabular} & $\begin{array}{r}0 \cdot 1 \\
0 \cdot 4 \\
0 \cdot 2 \\
0 \cdot 3 \\
12 \cdot 1\end{array}$ \\
\hline
\end{tabular}

* The figures in brackets give the lactic acid formation per ml. muscle extract.

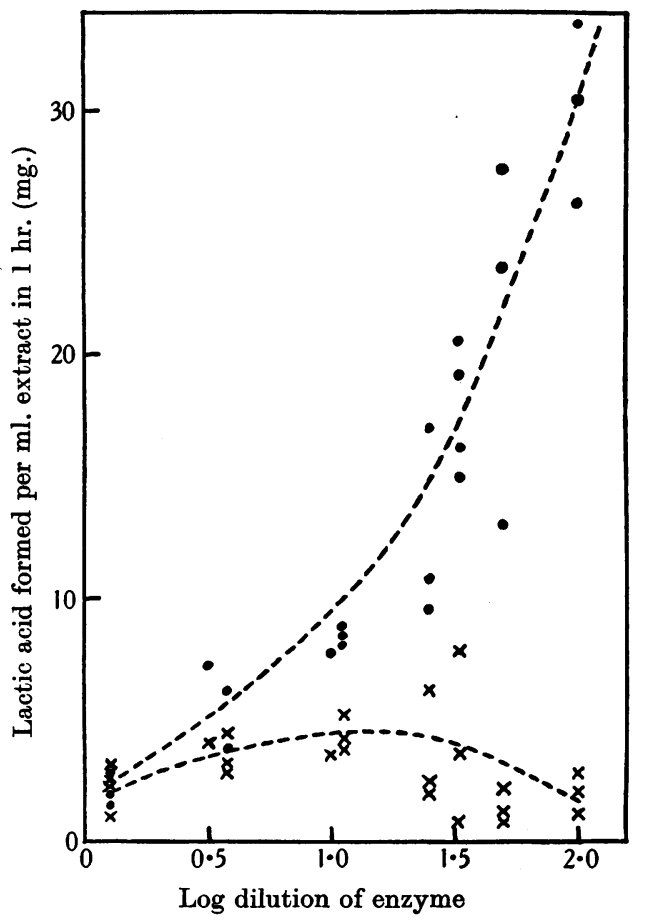

Fig. 1. Effect of dilution of enzyme on rate of glycolysis in presence of (a) boiled muscle extract $\cdots \cdots \cdot(b) \mathrm{ATP}+\mathrm{Mg} \times \cdots \times$. 
The figures are typical of numerous experiments of this kind. They show clearly that when the muscle extract is not diluted much, the use as coenzyme of boiled extract or adenosinetriphosphate $+\mathrm{Mg}^{++}$has the same effect, which is in accordance with the results of Lohmann. With more diluted extracts adenosinetriphosphate $+\mathrm{Mg}^{++}$is less effective than is boiled muscle extract, the disparity increasing with increasing dilution of the extract. With a suitable dilution, varying from $1 / 20$ to $1 / 50$, more than ten times as much lactic acid is formed in the presence of the boiled extract than in the presence of the pure coenzymes alone. It is interesting to note that the activity of the enzyme solution itself appears to increase with dilution. This is evident when the lactic acid formation per ml. muscle extract used, instead of that formed in $5 \mathrm{ml}$. of reaction mixture, is plotted on a graph against the degree of dilution of the extract. Fig. 1 is constructed in this way from results, such as those given in Table I, obtained with extracts prepared on eight different occasions.

It is seen from the graph that the glycolytic activity of muscle extracts in the presence of boiled extract increases with the dilution of the extracts. This is a curious feature of glycolysis in muscle extracts, and no explanation of it can be offered at present. In the presence of only adenosinetriphosphate and $\mathrm{Mg}^{++}$, on the other hand, the disposition of the points on the graph indicates that an additional factor is operating, tending to decrease the activity as dilution increases, and becoming dominant at the higher dilutions.

In the glycolysis tests with the pure coenzymes it was observed that during the incubation much of the protein of the muscle extract had been coagulated and was present at the end as a stringy white precipitate. When boiled extract was present no such precipitate was formed. It seemed possible that this coagulation might be accompanied by destruction of part of the enzyme system,

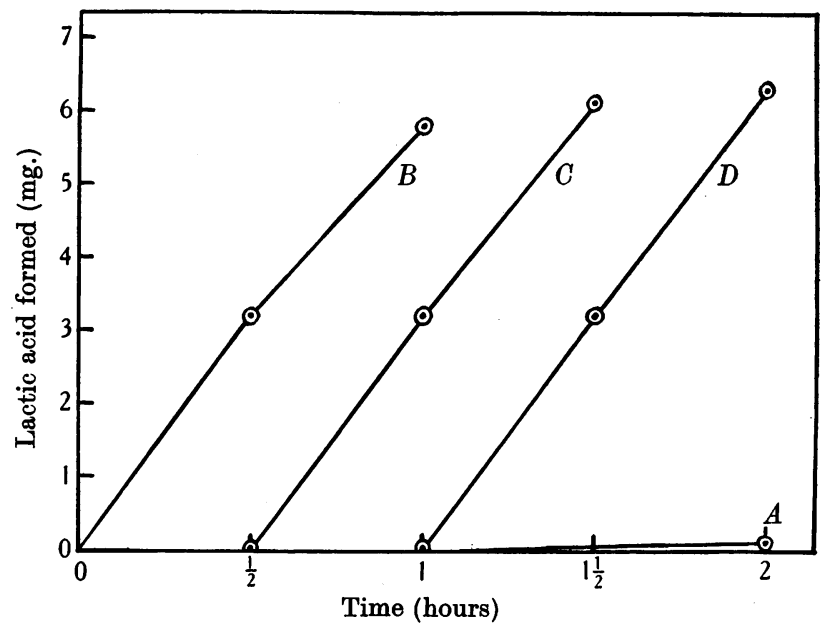

Fig. 2. Stability of enzyme system during incubation. Enzyme, $2.0 \mathrm{ml}$. GP (4) (see following section of paper). $M / 2000$ adenosinetriphosphate, $M / 250 \mathrm{Mg}^{++}$. Incubation at $37^{\circ} .0 \cdot 3 \mathrm{ml}$. boiled muscle extract (10 times concentrated) added from "Keilin tube" to $B$, at beginning of incubation; $C$, after $30 \mathrm{~min}$. incubation; $D$, after $60 \mathrm{~min}$. incubation.

and that the superior effect of boiled extract might be due to a protective action on the enzyme proteins rather than to the presence in it of an additional coenzyme. This possibility was tested in an experiment in which boiled extract 
was added to enzyme solutions which had been incubated for different times with starch, adenosinetriphosphate and $\mathrm{Mg}^{++}$. The results showed conclusively that a preliminary incubation for a period of $1 \mathrm{hr}$. did not diminish the subsequent response to the addition of boiled extract. The failure of adenosinetriphosphate $+\mathrm{Mg}^{++}$to activate glycolysis is therefore not the result of any injury to the enzymes which control the process. The curves given in Fig. 2 illustrate this point.

The disparate effects of adenosinetriphosphate $+\mathrm{Mg}^{++}$and boiled muscle extract in the activation of diluted dialysed muscle extracts are most readily explained by supposing $(a)$ that muscle extract contains some coenzyme which is necessary in glycolysis, other than adenosinetriphosphate and $\mathrm{Mg}^{++} ;(b)$ that some of this additional coenzyme is strongly adsorbed on to part of the enzyme system or other colloid in the extract, so that a sufficient quantity remains after dialysis to give maximum activation of the enzyme system on addition of adenosinetriphosphate $+\mathrm{Mg}^{++}$, unless the enzyme with its associated coenzyme is much diluted; (c) that the complete coenzyme system of boiled extract consists of adenosinetriphosphate, $\mathrm{Mg}^{++}$and some as yet unidentified factor. On the basis of these assumptions attempts were made to obtain more satisfactory coenzyme-free muscle extracts, i.e. extracts not activated by adenosinetriphosphate $+\mathrm{Mg}^{++}$, but activated by boiled muscle extract, even when only moderately diluted. It will be convenient to refer to such coenzyme-free extracts as "apomyozymase" solutions.

\section{Experiments with phosphate extracts of washed muscle}

It was found that if minced rabbit muscle were extracted repeatedly with distilled water until the glycolytic enzyme system could no longer be detected in the extracts and the pulp then extracted with $\mathrm{Na}_{2} \mathrm{HPO}_{4}$ solution, a very active enzyme solution was obtained. This phosphate extract often showed a greater glycolytic activity than did the first aqueous extract from the same muscle. Successive phosphate extracts were made from the same pulp in the following manner, and their properties were examined.

The muscle was cooled, minced and suspended in 5 vol. of distilled water. After standing $15 \mathrm{~min}$. at room temperature, with occasional stirring, it was squeezed as dry as possible in linen and the washing twice repeated. The washed muscle was then ground in a mortar with a little sand and a volume of $1 \% \mathrm{Na}_{2} \mathrm{HPO}_{4}$ solution equal to $1 \frac{1}{2}$ times the original volume of the muscle, allowed to stand for 15 min. and again squeezed in linen. Further extracts were made in the same way but using $0.5 \%$ phosphate; the phosphate concentrations in all the extracts were then roughly the same, viz. $1 \mathrm{mg}$. $P$ per $\mathrm{ml}$. The extracts were filtered through paper or glass wool and their $p H$ adjusted to 7.4. Repeated extraction in this way gave a series of extracts of activities similar to those shown in Table II. It will be convenient to refer to such phosphate

Table II. Lactic acid formation by phosphate extracts of washed rabbit muscle

mg. lactic acid formed in $1 \mathrm{hr}$. with

$\begin{array}{ccc}\text { Muscle extract } & \begin{array}{c}\text { Boiled } \\ \text { extract }\end{array} & \begin{array}{c}\text { Adenosinetri- } \\ \text { phosphate }+\mathrm{Mg}^{++}\end{array} \\ \text {GP (1)-see text } & 16 \cdot 6 & 12 \cdot 7 \\ \text { GP (2) } & 12 \cdot 2 & 9 \cdot 9 \\ \text { GP (3) } & 11 \cdot 3 & 2 \cdot 4 \\ \text { GP (4) } & 10 \cdot 1 & 0 \cdot 5 \\ \text { GP (5) } & 7 \cdot 1 & 0 \cdot 3\end{array}$


extracts as GP (1), GP (2) and so on, the numeral indicating the first, second or further extract from one pulp.

The relative activation of the extracts in such a series by boiled muscle and by adenosinetriphosphate $+\mathrm{Mg}^{++}$suggests that the additional coenzymic factor is extracted from the muscle pulp more completely in the earlier phosphate extracts than is the enzyme system itself. The later extracts are seen to be little activated by adenosinetriphosphate $+\mathrm{Mg}^{++}$, though they still show a high activity in the presence of boiled extract. The results of a number of such experiments are plotted in Fig. 3, in which the effectiveness of adenosine-

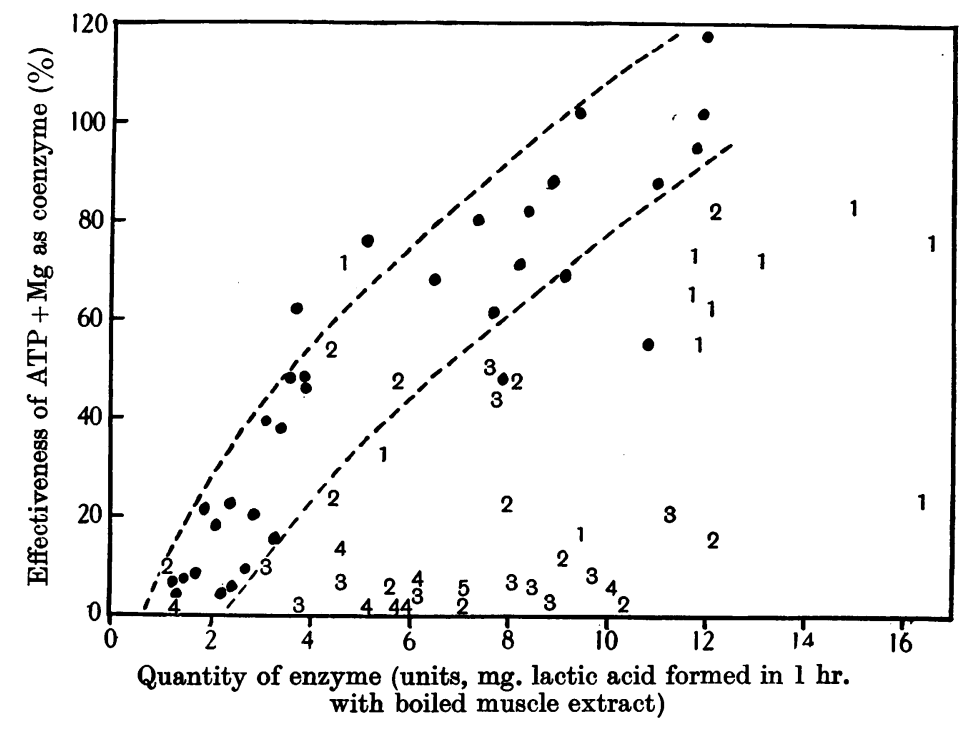

Fig. 3. Dots refer to dialysed aqueous muscle extracts. The figures $1,2,3$ and 4 refer to first, second, third and fourth phosphate extracts of washed muscle.

triphosphate $+\mathrm{Mg}^{++}$as coenzyme, i.e. the lactic acid formation in the presence of adenosinetriphosphate $+\mathrm{Mg}^{++}$expressed as a percentage of that formed in the presence of boiled extract, is plotted against the lactic acid formation in the presence of boiled extract. The latter figure we may regard as a measure of the concentration of the enzyme system-it is the only indication of this quantity which can at present be obtained. A study of the graph shows that the points referring to ordinary dialysed aqueous extracts of muscle fall within the fairly limited band between the dotted lines. That is to say the effectiveness of adenosinetriphosphate $+\mathrm{Mg}^{++}$as coenzyme with such extracts diminishes progressively with decreasing enzyme concentration. Most of the phosphate extracts give points falling below this band, and the third and fourth phosphate extracts points quite near the base line. Many of the extracts GP (3) and GP (4) have therefore the desired properties of $(a)$ satisfactory enzyme concentration, indicated by high glycolytic activity in the presence of the complete coenzyme system (boiled extract), and (b) relative freedom from the new coenzymic factor, indicated by absence of activation by adenosinetriphosphate $+\mathrm{Mg}^{++}$. Extracts of this type have been used in further experiments on the nature of the coenzyme system. 
It is of interest to mention that sheep's heart muscle, when washed and extracted with phosphate solution in the same way, gives an extract with glycolytic properties apparently similar to those of the skeletal muscle extracts. Examples are given in Table III. The properties of these extracts have not yet been more closely studied.

Table III. Lactic acid formation by phosphate extract of washed sheep's heart

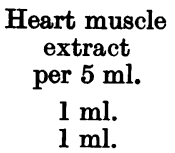
mg. lactic acid formed in $1 \mathrm{hr}$. with

$\begin{array}{cc}\begin{array}{c}\text { Boiled } \\ \text { extract }\end{array} & \begin{array}{c}\text { Adenosinetri- } \\ \text { phosphate }+\mathrm{Mg}^{++} \\ 3.1\end{array} \\ 4.8 & 0.1 \\ & 0.4\end{array}$

\section{Cozymohexase}

Bauer [1936] considers that an important intermediate reaction in glycolysis, namely, the conversion of hexosediphosphate into triosephosphate by the enzyme zymohexase, is facilitated by a coenzyme. This he demonstrated by the observation that in very dilute (2000-3000-fold) muscle extracts the reaction is very slow, but can be accelerated by the addition of boiled extract. The cozymohexase is intimately associated with colloidal matter in the extracts and is not removed by dialysis. It was possible that the results described in the preceding sections of this paper might be due to a deficiency of cozymohexase. The action of the enzyme solutions upon hexosediphosphate, in the absence of any added coenzyme, was therefore examined. Inorganic phosphate was estimated by the method of Fiske \& Subbarow [1925]. Triosephosphate was estimated in the trichloroacetic acid filtrates by measurement of the increase in inorganic $\mathrm{P}$ produced in $\mathbf{1 5} \mathrm{min}$. at room temperature by the addition of an equal volume of $2 \mathrm{~N} \mathrm{NaOH}$. Hexosediphosphate $\mathrm{P}$ was calculated from the amount of inorganic $\mathrm{P}$ set free by $2 \mathrm{hr}$. hydrolysis in $\mathrm{N} \mathrm{HCl} \mathrm{at} 100^{\circ}$, due allowance being made for the triosephosphate $P$ present and for the fact that only $80 \%$ of the hexosediphosphate $\mathbf{P}$ is liberated by such treatment. It was found that the conversion of hexosediphosphate into triosephosphate took place rapidly in the enzyme solutions used, without requiring added coenzyme (Table IV). Cozymohexase is thus not the agent with which this paper is concerned.

\section{Table IV. Conversion of hexosediphosphate into triosephosphate in diluted muscle extracts and in apomyozymase solutions}

Exp. 1. Enzymo-0.1 ml. DM 20; with $0.5 \mathrm{ml} .2 .6 \% \mathrm{NaHCO}_{3}$ and $1.0 \mathrm{ml}$. $\mathrm{Na}$ hexosediphosphate containing $1 \cdot 10 \mathrm{mg}$. Total volume $5 \mathrm{ml}$. Incubation at $37^{\circ}$ in $\mathrm{N}_{2}+5 \% \mathrm{CO}_{2}$.

Period of incubation (min.)

Inorganic $P$ after incubation

Triosephosphate $P$ after incubation

Hexosediphosphate $\mathbf{P}$ after incubation
0

\section{$0 \cdot 11$}

0.00

$1 \cdot 10$
30

mg. $\mathrm{P}$ per $5 \mathrm{ml}$.

Exp. 2. Enzyme-2.0 ml. GP (4); with $0.5 \mathrm{ml} .2 \cdot 6 \% \mathrm{NaHCO}_{3}$ and $1.0 \mathrm{ml}$. $\mathrm{M} / 20 \mathrm{Na}$ hexosediphosphate. Total volume $5 \mathrm{ml}$. Incubation as in Exp. 1 above.

Period of incubation (min.)

0

10

mg. P per $5 \mathrm{ml}$.

Inorganic $\mathbf{P}$ after incubation

Triosephosphate $\mathrm{P}$ after incubation

Hexosediphosphate $\mathbf{P}$ after incubation

$\begin{array}{lll}2.18 & 2.19 & 2.22 \\ 0.00 & 0.72 & 0.76 \\ 3.08 & 2.38 & 2.38\end{array}$




\section{Cozymase in muscle glycolysis}

The chemical similarity between the course of lactic acid formation in muscle extracts and alcoholic fermentation in yeast juice has long been stressed. The far-reaching nature of the analogy, and the identity of many of the intermediate reactions in the two processes, have been clearly defined by recent publications of Embden, Meyerhof and their colleagues. It seemed therefore likely that in glycolysis as in alcoholic fermentation some coenzyme analogous to or identical with cozymase might be required in the oxido-reductive stages of the chain of reactions. The effects of boiled yeast extract and of purified cozymase upon the course of glycolysis in apomyozymase solutions were studied. The addition of boiled yeast extract or cozymase together with adenosinetriphosphate and $\mathrm{Mg}^{++}$brought about a measurable lactic acid formation which was, however, still small compared with that resulting from the addition of boiled muscle extract. In activating apozymase with cozymase it is the usual practice to add a trace of hexosediphosphate, in order to eliminate a long latent period which the reaction otherwise exhibits. This expedient was adopted in the present case, again with a small favourable result, but the rate of glycolysis remained far below the boiled extract-activated level. Results of such experiments are given in Table V. They seemed to prove conclusively that the substance in boiled muscle extract which was necessary together with adenosinetriphosphate and $\mathrm{Mg}^{++}$to complete the coenzyme system was neither cozymase nor cozymase + hexosediphosphate.

Table V. Effects of boiled yeast extract and of purified cozymase on lactic acid formation in diluted muscle extracts and in apomyozymase solutions.

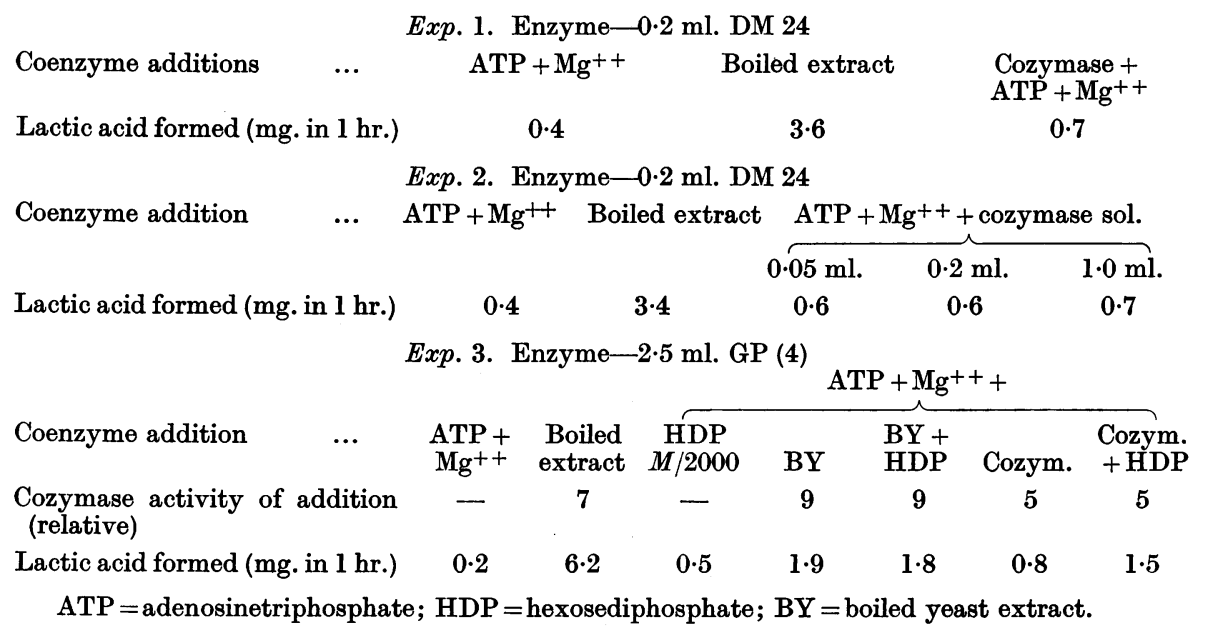

Meyerhof \& Ohlmeyer [1936], using very thoroughly dialysed aqueous muscle extracts, have recently observed that the reaction between triosephosphate and pyruvic acid, giving phosphoglyceric and lactic acids, takes place in such extracts only if cozymase is added. If the presence of a trace of hexosediphosphate is necessary for cozymase to exert its effect in this case, this necessity was not revealed since hexosediphosphate itself was added in excess as substrate, the triosephosphate being then produced from it by the zymohexase in the muscle extract. The extracts used by these workers were unable to form lactic acid from glycogen even in the presence of both the adenosinetriphosphate-adenylic 
acid system and cozymase, and whether they could do so in the presence of boiled muscle extract is not stated. $50 \%$ of the maximum activation of lactic acid formation was obtained with a cozymase concentration of $1 \cdot 2 \gamma$ per $\mathrm{ml}$. We have already referred to the difficulty of comparing precisely our cozymase preparations, in respect of their activity, with those of other workers. From a comparison of our purified preparations with crude yeast extract it is possible to compute roughly that our preparations probably contain $20-30 \%$ of pure cozymase, and that the concentration of the pure substance used in our experiments was of the order of $100 \gamma$ per ml. These considerations led us to resume the study of the influence of cozymase on the glycolytic activity of the apomyozymase solutions which have been described.

The data from the extended series of experiments showed that on some occasions extracts of the GP (4) type were activated to a much greater extent by the addition of adenosinetriphosphate $+\mathrm{Mg}^{++}+$cozymase + hexosediphosphate than had been observed in the earlier experiments. Although the lactic acid production in the presence of this combination of coenzymes was usually less than $20 \%$ of that resulting from the addition of boiled muscle extract, there were cases in which 26, 55, 90 and $125 \%$ of the latter figure was reached. This variation may be seen by referring to Table VI, where, in the last column, the lactic acid formed through the agency of the combined coenzymes is given as a percentage of that formed in the presence of boiled muscle extract.

\section{Table VI. Effect of cozymase and hexosediphosphate on lactic acid formation in apomyozymase solutions}

Cozymase added as indicated in amount equivalent in cozymase activity to $2.0 \mathrm{ml}$. boiled muscle extract

Lactic acid formed in $1 \mathrm{hr}$. with the following additions

\begin{tabular}{|c|c|c|c|c|c|c|}
\hline Exp. & Enzyme & $\begin{array}{c}\text { Adenosinetri- } \\
\text { phosphate } \\
+\mathrm{Mg}^{++}\end{array}$ & $\begin{array}{c}\text { ATP, Mg, } \\
\text { HDP } \\
(M / 2000)\end{array}$ & $\begin{array}{c}\mathrm{ATP} \\
\mathrm{Mg}^{++}, \\
\text {cozymase }\end{array}$ & $\begin{array}{c}\text { ATP, } \mathrm{Mg}^{++} \\
\text {HDP, } \\
\text { cozymase }\end{array}$ & $\begin{array}{c}\text { Boiled } \\
\text { muscle } \\
\text { extract }\end{array}$ \\
\hline 1 & $3.0 \mathrm{ml} . \mathrm{GP}(4)$ & $0 \cdot 3$ & $0 \cdot 6$ & $0 \cdot 3$ & 1.0 & $3 \cdot 8$ \\
\hline 2 & $2.0 \mathrm{ml}$. GP (4) & 0.2 & - & - & 0.5 & $4 \cdot 6$ \\
\hline 3 & $3.0 \mathrm{ml}$. GP (4) & $0 \cdot 3$ & $0 \cdot 7$ & $0 \cdot 7$ & $5 \cdot 2$ & $5 \cdot 8$ \\
\hline 4 & 3.0 ml. GP (4) & $0 \cdot 2$ & $0 \cdot 4$ & $0 \cdot 4$ & $3 \cdot 2$ & $5 \cdot 8$ \\
\hline 5 & $2.0 \mathrm{ml} . \mathrm{GP}(3)$ & $0 \cdot 3$ & - & - & $2 \cdot 9$ & $8 \cdot 2$ \\
\hline 6 & $2.0 \mathrm{ml}$. GP (4) & 0.0 & - & - & $0 \cdot 3$ & $5 \cdot 2$ \\
\hline 7 & $2.0 \mathrm{ml} . \mathrm{GP}(3)$ & $0 \cdot 8$ & $3 \cdot 8$ & $1 \cdot 3$ & $7 \cdot 6$ & $9 \cdot 7$ \\
\hline 8 & $2.0 \mathrm{ml} . \mathrm{GP}(4)$ & $0 \cdot 1$ & $0 \cdot 4$ & $0 \cdot 1$ & $0 \cdot 6$ & $6 \cdot 0$ \\
\hline 9 & $2.0 \mathrm{ml} . \mathrm{GP}(3)$ & $0 \cdot 3$ & $1 \cdot 1$ & $0 \cdot 4$ & $3 \cdot 0$ & $5 \cdot 8$ \\
\hline 10 & $2.0 \mathrm{ml} . \mathrm{GP}(4)$ & $0 \cdot 0$ & $0 \cdot 1$ & $0 \cdot 1$ & $0 \cdot 3$ & $4 \cdot 0$ \\
\hline 11 & $2.0 \mathrm{ml}$. GP (4) & $0 \cdot 0$ & - & - & $0 \cdot 6(1)^{*}$ & $5 \cdot 5$ \\
\hline 12 & $2.0 \mathrm{ml} . \mathrm{GP}(4)$ & $0 \cdot 3$ & $1 \cdot 6$ & $0 \cdot 6$ & $\begin{array}{l}0 \cdot 6(2)^{4} \\
4 \cdot 5\end{array}$ & $3 \cdot 6$ \\
\hline 13 & $0.2 \mathrm{ml} . \mathrm{DM}$ & $0 \cdot 6$ & $0 \cdot 7$ & $0 \cdot 6$ & $0 \cdot 6$ & $3 \cdot 2$ \\
\hline
\end{tabular}

After consideration of the data presented in Table VI the following conclusions seem justified: $(a)$ it is possible to obtain solutions of the glycolytic enzyme system with coenzyme requirements which are not met by the addition of adenosinetriphosphate, $\mathrm{Mg}^{++}$, cozymase and hexosediphosphate (Exps. 2, 6, 8,10 and 11 in Table VI); (b) it is also possible to obtain enzyme solutions which, while they are not activated by adenosinetriphosphate and $\mathrm{Mg}^{++}$, react with 
considerable and sometimes full activity when cozymase and hexosediphosphate are also added (Exps. 3, 4 and 12 in Table VI); (c) for the activation of extracts of the last-mentioned type both cozymase and hexosediphosphate are necessary. It seems probable that the variation in the properties of GP (4) extracts is determined by slight differences in the condition of the muscle or in the precise details of the extraction procedure. The difficulty of removing the coenzymes from the enzyme remaining in the muscle pulp appears to increase in the following order; adenosinetriphosphate and $\mathrm{Mg}^{++}$, hexosediphosphate and cozymase, the unidentified coenzyme which must still be present in enzyme solutions which are activated by addition of the former compounds. This view is borne out by a consideration of the three pairs of Exps. 5 and 6, 7 and 8, and 9 and 10 in Table VI. In the first experiment of each pair the enzyme solution used was the third phosphate extract (GP (3)), and in the second the fourth phosphate extract (GP (4)), from the same pulp. None of the extracts was activated by adenosinetriphosphate and $\mathrm{Mg}^{++}$, but in each pair the further addition of cozymase and hexosediphosphate caused a considerable lactic acid formation by the GP (3) extract and had very little effect on the GP (4) extract. It has also been shown that diluted aqueous muscle extracts are not activated by the combined effect of adenosinetriphosphate, $\mathrm{Mg}^{++}$, cozymase and hexosediphosphate. An example is given in Table VI (Exp. 13).

These experiments therefore support the belief of Meyerhof \& Ohlmeyer that cozymase is a necessary coenzyme in glycolysis in muscle extracts. They also make it clear that some as yet unidentified coenzyme plays an equally important part.

\section{Properties of the unidentified coenzyme in boiled muscle extract}

(1) Behaviour on dialysis. Boiled muscle extract contains a certain amount of non-dialysable colloidal material, but if it is dialysed in a collodion sac against distilled water the full coenzyme activity is found in the dialysate. This is demonstrated by the experimental results shown in Table VII.

\section{Table VII. Dialysability of coenzymes in boiled muscle extract}

Enzyme solution used: Exp. 1, DM 4, 0.1 ml.; Exp. 2, DM 24, 0.2 ml.

\begin{tabular}{|c|c|c|c|}
\hline \multirow[b]{2}{*}{ Coenzyme solution } & \multirow{2}{*}{$\begin{array}{c}\text { Volume } \\
\text { coenzyme } \\
\text { solution } \\
\text { ml. }\end{array}$} & \multicolumn{2}{|c|}{ Lactic acid formation in $1 \mathrm{hr}$} \\
\hline & & $\begin{array}{l}\text { Exp. } 1 \\
\mu l . \mathrm{CO}_{2}\end{array}$ & $\begin{array}{l}\text { Exp. } 2 \\
\text { mg. }\end{array}$ \\
\hline Boiled extract & $2 \cdot 0$ & 637 & $3 \cdot 2$ \\
\hline Adenosinetriphosphate $(M / 200)+\mathrm{Mg}^{++}(M / 25)$ & 0.5 & 70 & $0 \cdot 6$ \\
\hline $\begin{array}{l}\text { Dialysate. Boiled extract dialysed against } \\
\frac{1}{3} \text { vol. distilled water for } 4 \mathrm{hr} \text {. }\end{array}$ & $2 \cdot 5$ & 543 & $3 \cdot 0$ \\
\hline Ditto + ATP $+\mathbf{M g}^{++}$ & - & 657 & - \\
\hline $\begin{array}{l}\text { Boiled extract dialysed against large vol. } \\
\text { distilled water for } 16 \mathrm{hr} \text {. }\end{array}$ & $2 \cdot 0$ & 11 & - \\
\hline Ditto + ATP $+\mathrm{Mg}^{++}$ & - & 69 & - \\
\hline
\end{tabular}

Evidence that the Meyerhof enzyme solution still contains at least three coenzymes even after $24 \mathrm{hr}$. dialysis has already been presented. In view of the ease with which all the coenzymes are dialysable in the boiled extract, attempts were made to remove them from aqueous muscle extracts by more prolonged dialysis against distilled water and against phosphate buffer solutions of different $p \mathrm{H}$ values. The extracts were dialysed for periods of up to 7 days against large 
volumes of solutions which were frequently renewed, but no success was achieved. The length and conditions of dialysis had no significant effect upon the degree of activation brought about by adenosinetriphosphate and $\mathrm{Mg}^{++}$ (Table VIII).

\section{Table VIII. Effect of prolonged dialysis on coenzyme requirements of muscle extracts}

\begin{tabular}{|c|c|c|c|c|c|}
\hline \multirow[b]{2}{*}{ Exp. } & \multirow[b]{2}{*}{$\begin{array}{l}\text { Extract dialysed } \\
\text { against }\end{array}$} & \multirow{2}{*}{$\begin{array}{c}\text { Period of } \\
\text { dialysis } \\
\text { (hr.) }\end{array}$} & \multirow{2}{*}{$\begin{array}{l}\text { Vol. of extract } \\
\text { used in glyco- } \\
\text { lysis test } \\
\text { (ml. per } 5 \text { ml.) }\end{array}$} & \multicolumn{2}{|c|}{ Lactic acid formed in $1 \mathrm{hr}$. (mg.) } \\
\hline & & & & $\begin{array}{c}\text { With ATP } \\
+\mathrm{Mg}^{++}\end{array}$ & $\begin{array}{l}\text { With boiled } \\
\text { muscle extract }\end{array}$ \\
\hline 1 & $\begin{array}{l}\text { Distilled water } \\
\text { Distilled water } \\
\text { Phosphate } M / 15 p \mathrm{H} 7 \cdot 4\end{array}$ & $\begin{array}{r}22 \\
170 \\
170\end{array}$ & $\begin{array}{l}4 \\
4 \\
4\end{array}$ & $\begin{array}{l}7 \cdot 8 \\
6 \cdot 9 \\
6 \cdot 8\end{array}$ & $\begin{array}{l}8 \cdot 9 \\
8 \cdot 4 \\
9 \cdot 6\end{array}$ \\
\hline 2 & $\begin{array}{l}\text { Distilled water } \\
\text { Phosphate } M / 15 p \mathrm{H} 6.0 \\
\text { Phosphate } M / 15 p \mathrm{H} 7.0\end{array}$ & $\begin{array}{r}20 \\
120 \\
120\end{array}$ & $\begin{array}{l}3 \cdot 5 \\
3 \cdot 5 \\
3 \cdot 5\end{array}$ & $\begin{array}{r}11 \cdot 2 \\
9 \cdot 5 \\
10 \cdot 7\end{array}$ & $\begin{array}{l}11 \cdot 8 \\
10 \cdot 5 \\
11 \cdot 7\end{array}$ \\
\hline 3 & Phosphate $M / 15 p \mathrm{H} 8.0$ & 168 & 4 & $8 \cdot 6$ & $10 \cdot 8$ \\
\hline
\end{tabular}

(2) Stability of the coenzyme system. Aqueous extracts of muscle were kept for several days in the refrigerator, with the object of allowing enzymic destruction of adenosinetriphosphate in these extracts to take place. They were then boiled and filtered, and the hydrogen ion concentration adjusted to $p \mathbf{H ~} \mathbf{7 \cdot 4}$. The boiled extract thus obtained was found to have little or no coenzyme activity unless adenosinetriphosphate were added to it (Table IX). The other

Table IX. Lactic acid formation in the presence of "inactive" (adenosinetriphosphate-deficient) boiled muscle extract

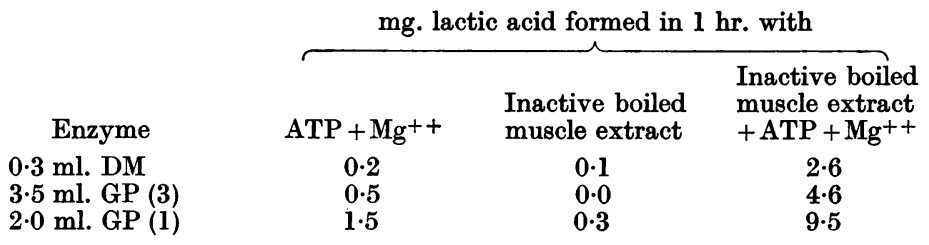

components of the coenzyme system are therefore more stable towards autolytic action than is adenosinetriphosphate.

The stability of the coenzyme system to heat in acid, neutral and alkaline solution was studied. In order to test the effect of heating in the presence of $N \mathrm{HCl}$ or $N \mathrm{NaOH}$ and at the same time avoid the consequences of the introduction of a considerable quantity of $\mathrm{NaCl}$ into the boiled extract by this treatment together with the subsequent neutralization, boiled extract was first concentrated under reduced pressure to one-tenth of its original volume. Samples were then heated at $100^{\circ}$ for $1 \mathrm{hr}$. at different $p \mathrm{H}$ values, and the coenzyme activities after this treatment were tested. The results are given in Table $\mathbf{X}$. Adenosinetriphosphate was added to all the test reaction mixtures, since only information about the fate of coenzymes other than this was required. It is seen from Table $X$ that the activity of boiled muscle extract in respect of these other coenzymes is completely destroyed by heating in strongly acid solution. The activity is however considerably restored (50 and $75 \%$ in the two experiments) by the addition of hexosediphosphate and cozymase. At slightly acid, 
Table X. Stability to heat of the coenzyme in boiled muscle extract

Boiled extract concentrated $\times 10$ under reduced pressure.

$2.0 \mathrm{ml}$. concentrate heated at $100^{\circ}$ for $1 \mathrm{hr}$. after the following additions:
A. $2 \cdot 0 \mathrm{ml} .2 \mathrm{~N} \mathrm{HCl}$
$p \mathrm{H}$ c. 1
B. $0 \cdot 25 \mathrm{ml} .2 \mathrm{~N} \mathrm{HCl}+1 \cdot 75 \mathrm{ml}$. water
C. $2.0 \mathrm{ml}$. water
$p \mathrm{H} c .5 \cdot 5$
D. $2.0 \mathrm{ml} .2 \mathrm{~N} \mathrm{NaOH}$
$p \mathrm{H}$ c. $\mathbf{7 \cdot 4}$
$p \mathrm{H}$ c. 12-13

After heating each was neutralized to $p \mathrm{H} 7 \cdot 4$ and made up to $6 \mathrm{ml}$. with water.

Thus $0.6 \mathrm{ml}$. final solution should be equivalent to $0.2 \mathrm{ml}$. boiled extract concentrate and to $2.0 \mathrm{ml}$. fresh boiled extract, and this volume was used in the tests.

Glycolysis tests. Enzyme, $2 \cdot 0 \mathrm{ml}$. GP (4). $M / 2000$ adenosinetriphosphate and $M / 250 \mathrm{Mg}^{++}$ added in each test.

\begin{tabular}{|c|c|c|c|c|}
\hline \multirow[b]{2}{*}{ Solution added } & \multicolumn{2}{|c|}{ Exp. 1} & \multicolumn{2}{|c|}{ Exp. 2} \\
\hline & - & $\begin{array}{l}\text { After further } \\
\text { addition of } \\
\text { cozymase and } \\
\text { hexosediphosphate }\end{array}$ & - & $\begin{array}{l}\text { After further } \\
\text { addition of } \\
\text { cozymase and } \\
\text { hexosediphosphate }\end{array}$ \\
\hline - & $0 \cdot 1$ & 0.5 & $0 \cdot 0$ & 0.4 \\
\hline BEA concentrate $0.2 \mathrm{ml}$. & $6 \cdot 0(4 \cdot 3)$ & - & $6 \cdot 2$ & $6.5(4 \cdot 0)$ \\
\hline $\mathbf{A}$ & $0 \cdot 1$ & $2 \cdot 2$ & $0 \cdot 2$ & $3 \cdot 1$ \\
\hline B & 1.5 & $5 \cdot 7$ & $2 \cdot 0$ & $7 \cdot 2$ \\
\hline C & $1 \cdot 1$ & $6 \cdot 2$ & $1 \cdot 5$ & $6 \cdot 7$ \\
\hline $\mathrm{D}$ & 0.9 & $3 \cdot 9$ & $1 \cdot 3$ & $5 \cdot 6$ \\
\hline
\end{tabular}

The figure in brackets indicates the lactic acid formation when $24 \mathrm{mg}$. $\mathrm{NaCl}$ had been added to the control boiled extract. This amount of $\mathrm{NaCl}$ is equivalent to that introduced into the boiled extracts $A$ and $D$ by the treatment with acid and alkali, and it is with the figure in brackets that the lactic acid productions under $\mathrm{A}$ and $\mathrm{D}$ must be compared.

neutral and even strongly alkaline reactions the unidentified coenzyme is unaffected, since boiled muscle extract heated under these conditions is still fully competent to activate apomyozymase solutions if hexosediphosphate and cozymase are added to it. It is remarkable that even in the absence of this supplement some activity (resulting in 18-32\% of the maximum lactic acid formation) is shown; one would have expected that by heating in $\mathrm{N} \mathrm{NaOH}$ the cozymase in the boiled extract would have been completely destroyed. This point will be referred to again in the discussion.

When boiled extract was evaporated to dryness and the residue ignited, the addition of adenosinetriphosphate, cozymase and hexosediphosphate to the ash did not restore the coenzymic activity. The other coenzyme is thus organic in nature.

\section{Esterification of phosphoric acid}

Apomyozymase solutions, though they are unable to convert starch into lactic acid in the presence of adenosinetriphosphate and $\mathrm{Mg}^{++}$, bring about a considerable esterification of phosphoric acid under these conditions. In the presence of the complete coenzyme system esterification is at first rapid, but the esters are decomposed in the later stages. The results of a typical experiment illustrating these points are presented in Fig. 4. In the absence of adenosinetriphosphate we have never observed any change in the concentration of inorganic phosphate, which suggests that esterification without coenzymic facilitation, such as has been reported from Parnas's laboratory [Ostern et al. 1936], plays no part in glycolysis under the conditions obtaining in our experi- 
ments. These problems, and the nature of the esters formed, will be dealt with more fully in a later communication.

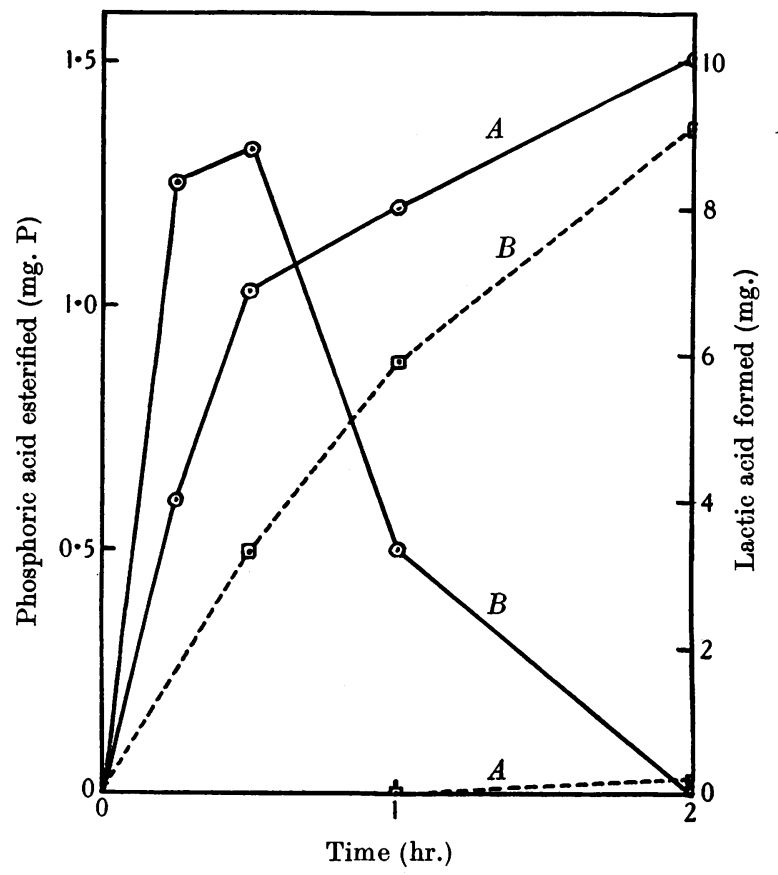

Fig. 4. Esterification and lactic acid formation in apomyozymase solutions. Enzyme solution, $2.0 \mathrm{ml}$. GP (4). $A$, with adenosinetriphosphate $(M / 2000) ; B$, with boiled muscle extract and $\mathrm{Mg}^{++}(M / 250)$. Continuous lines, esterification; dotted lines, lactic acid formation.

\section{Discussion}

There is now abundant evidence that cozymase can play an important part in glycolysis in muscle extracts. Meyerhof \& Ohlmeyer demonstrated its effect only in one of the intermediate reactions, namely, that between triosephosphate and pyruvic acid. Euler et al. [1937], using dialysed extracts of rat muscle, found it necessary to add cozymase and adenylic acid to bring about lactic acid formation from glycogen. In their experiments a trace of hexosediphosphate was also added, but no comment is made on this. These workers found that after quite a short period of dialysis $(3 \mathrm{hr}$. against $0.6 \% \mathrm{KCl})$ the necessity of adding cozymase became easily demonstrable. This has not been the experience of other workers with frog and rabbit muscle extracts. In our own experiments the demand for coenzymes other than adenosinetriphosphate and $\mathrm{Mg}^{++}$could not be demonstrated with satisfaction even after very prolonged dialysis, unless the extract were much diluted. It is possible that the species of animal used determines the difference in behaviour. Our own experiments, showing that certain preparations from rabbit muscle require both cozymase and hexosediphosphate, in addition to adenosinetriphosphate and $\mathrm{Mg}^{++}$, for the activation of lactic acid formation from starch, confirm in general the results of the authors cited above. The fact that certain other enzyme preparations are not activated by these coenzymes but only by boiled muscle extract has brought to light the 
intervention of a new coenzyme and opened up new possibilities. The chemical nature and function of this new coenzyme are at present unknown, but investigation of this problem is in progress.

It is interesting to find that after complete extraction of glycolytic enzyme system by the method of Meyerhof an even greater quantity of the same enzyme system may be obtained by extracting the muscle pulp with phosphate solutions. It appears that the enzyme is associated with proteins which are not soluble in distilled water but are soluble in phosphate solution. We have not sufficient evidence to say whether the phosphate ion has a specific effect, but the extraction is not achieved by the use of $0.6 \% \mathrm{KCl}$. It seems possible that the initial phosphate content of the muscle is able to bring part of the enzyme into solution, but that when the phosphate concentration is reduced by further extractions with water or $\mathrm{KCl}$ solutions the residual enzyme remains undissolved in the muscle pulp and can be brought into solution only by the addition of more phosphate.

The enzyme and coenzyme systems are evidently intimately associated with each other in the muscle tissue. The first aqueous extracts contain both enzyme and coenzyme, and the later aqueous extracts neither. The first phosphate extract of the washed muscle again contains both enzyme and coenzyme (except adenosinetriphosphate and $\mathrm{Mg}^{++}$) and it is only in the later phosphate extracts that any further separation begins to appear. Analysis of our results shows that the components of the glycolytic system (holomyozymase) stand in the following order with regard to the ease with which they are completely removed from muscle pulp by extraction with phosphate solution:

(1) Adenosinetriphosphate and $\mathrm{Mg}^{++}$.

(2) Hexosediphosphate.

(3) Cozymase.

(4) The new coenzyme.

(5) Apomyozymase.

The separation is in some cases only partial, but that this is the general order of extraction is shown by the preparation of extracts with properties as follows:

Coenzymes added

(1) Adenosinetriphosphate $+\mathrm{Mg}^{++}$

(2) As (1) + hexosediphosphate

(3) As (2) + cozymase

(4) Boiled extract

\section{Type of muscle extract activated by these coenzymes}

DM and GP (1)

GP (3) (partial and variable activation)

GP (3), occasionally GP (4)

GP (4) and GP (5)

Earlier in this paper it was suggested that the term apomyozymase might be used to denote glycolytic enzyme preparations which responded to the coenzymes in boiled extract but not to the addition of adenosinetriphosphate and $\mathrm{Mg}^{++}$. It is advisable to modify this definition, because it is now clear that not one but several other coenzymes are concerned. We suggest that the term apomyozymase might be applied to enzyme solutions which are activated by boiled extract but not by adenosinetriphosphate, $\mathrm{Mg}^{++}$, hexosediphosphate and cozymase. It must be remembered that such preparations still contain Bauer's cozymohexase; further restriction of the meaning of the term may be resorted to when methods of removing this coenzyme from the enzyme preparations are forthcoming.

Although the addition of hexosediphosphate and cozymase has in some cases been observed to play a decisive part in determining the onset of glycolysis, there remains some doubt as to whether the coenzymes in boiled extract are identical with these substances. The reason for this doubt is twofold. First, 
dialysed aqueous muscle extracts have always, in our experience, contained an adequate amount of coenzyme other than adenosinetriphosphate and $\mathbf{M g}^{++}$. Very slow dialysis of cozymase from muscle extract may not be unexpected, and may be analogous to the well-known slow rate of dialysis of this compound from fresh yeast juice [Buchner \& Rapp, 1898]. It is, however, difficult to understand why hexosediphosphate should not dialyse very readily, and the available data seem to show that unless it is supplemented with hexosediphosphate cozymase can have no effect. Secondly, the properties of the coenzyme system in respect of its thermostability are not easily reconciled with the known properties of cozymase. Meyerhof, Euler and their colleagues believe that the chief function of cozymase in glycolysis is that of a hydrogen-transporting coenzyme, and it is exceedingly probable that this view is correct. This function is very easily destroyed by heat in alkaline solution: Euler et al. [1937] heated cozymase for $5 \mathrm{~min}$. at $100^{\circ}$ in $N / 20 \mathrm{NaOH}$ to bring about this inactivation. It seems therefore quite impossible that boiled muscle extract after heating with its own volume of $2 \mathrm{~N} \mathrm{NaOH}$ at $100^{\circ}$ for $1 \mathrm{hr}$. should contain any active cozymase. Yet, as has been shown in Table X, boiled extract after such treatment was not found to be completely inactive. ${ }^{1}$ These considerations suggest that the hydrogen-transporting coenzyme in muscle glycolysis may not be identical with cozymase, although this substance appears to be able to take its place.

\section{SUMMARY}

1. Dialysed aqueous extracts of rabbit muscle were prepared by the method of Meyerhof. Such extracts when diluted twenty times or more failed to convert starch into lactic acid in the presence of adenosinetriphosphate and $\mathrm{Mg}^{++}$, but were able to do so in the presence of boiled muscle extract. The participation of coenzymes other than adenosinetriphosphate and $\mathrm{Mg}^{++}$was thus demonstrated.

2 . When washed muscle pulp was repeatedly extracted with $1 \frac{1}{2}$ vol. of $\mathrm{Na}_{2} \mathrm{HPO}_{4}$ solution a series of extracts was obtained the first four or five of which showed, when suitably activated, high glycolytic activity. The coenzyme requirement became progressively more extensive down the series. Thus the first extract was fully activated by the addition of adenosinetriphosphate and $\mathrm{Mg}^{++}$, the third extract was not activated by these substances but was glycolytically effective when cozymase and a little hexosediphosphate were also added, whilst the fourth extract only converted starch into lactic acid when boiled extract was present. Extracts were often found to have properties intermediate between these main types.

3. The experiments confirm the view that cozymase, or a coenzyme whose function can be exercised by cozymase, is an essential part of the glycolytic system. They also show that boiled muscle extract contains yet another essential and unidentified coenzyme.

4. It is suggested that the term "apomyozymsse" should denote preparations of the glycolytic enzyme system which are active in the presence of boiled extract but whose coenzyme requirement is not satisfied by adenosinetriphosphate, $\mathrm{Mg}^{++}$, hexosediphosphate and cozymase.

1 Note added 3 October, 1937. In writing this paragraph we overlooked the possibility that a part of the cozymase in boiled muscle extract may be in the reduced form. Reduced cozymase is much more resistant to heat in alkaline solution than is the oxidized form, and is stable to heating in $0 \cdot 1 \mathrm{~N} \mathrm{NaOH}$ at $100^{\circ}$ for 30 minutes [Adler, et. al., 1936]. It is possiblethat it is also stable to $\mathrm{N} \mathrm{NaOH}$ at $100^{\circ}$ for 60 minutes, and this might provide an alternative explanation of our results. 


\section{REFERENCES}

Adler, Hellström \& Euler (1936). Hoppe-Seyl. Z. 242, 225.

Barrenscheen \& Filz (1932). Biochem. Z. 250, 281.

Bauer (1936). Hoppe-Seyl. Z. 242, 15.

Buchner \& Rapp (1898). Ber. dtsch. chem. Ges. 31, 209.

Euler, Adler, Günther \& Vestin (1937). Hoppe-Seyl. Z. 247, 127.

Fiske \& Subbarow (1925). J. biol. Chem. 66, 375.

Friedemann, Cotonio \& Shaffer (1927). J. biol. Chem. 73, 335.

Lohmann (1931, 1). Biochem. Z. 241, 67.

(1931, 2). Naturwissenschaften, 19, 180.

Meyerhof (1926). Biochem. Z. 178, 395.

\& Ohlmeyer (1936). Naturwissenschaften, 24, 741.

Myrbäck (1928). Hoppe-Seyl. Z. 177, 158.

Ohlmeyer (1936). Biochem. Z. 287, 212.

Ostern, Guthke \& Terszakowec (1936). Hoppe-Seyl. Z. 243, 9. 